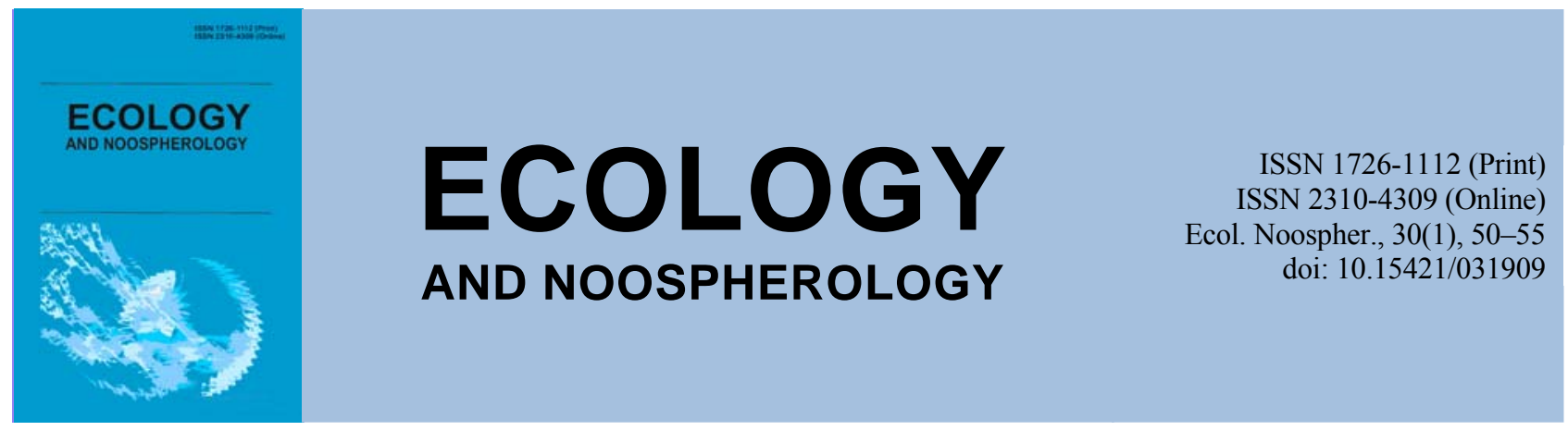

\title{
Influence of woody vegetation on the content of humus in chernozem soils
}

\author{
A. O. Huslystyi \\ Oles Honchar Dnipro National University, Dnipro, Ukraine
}

Article info

Received 11.12.2018

Received in revised form 25.12.2018

Accepted 06.01.2019

Oles Honchar Dnipro

National University,

Gagarin Ave., 72, Dnipro, 49010, Ukraine.

Tel.: +38-099-380-61-71

E-mail: guslistyj@i.ua

\begin{abstract}
Huslystyi, A. O. (2019). Influence of woody vegetation on the content of humus in chernozem soils. Ecology and Noospherology, 30(1), 50-55. doi:10.15421/031909
\end{abstract}

The literature sources on the influence of woody vegetation on the content of humus in chernozem soils were analyzed. In scientific literature, there are many articles from scholars from around the world on the study of the content of organic matter in the soil under various types of plantings. Proceeding from this, there is a need for comprehensive research on humus of reference black soil common. Separately there is the question of the influence of artificial forest plantations of different wood structure and light structure on the complex characteristics of ascending ordinary black soil. The importance of these studies is due to the complex ecological role played by humus in soils. As a result of the analysis of literary data, it was discovered that woody vegetation increases the content of organic matter and positively affects the black soils. Regularities of change in the humus state are connected, first of all, with the type of land use. Under each tree species there is a characteristic and peculiar humus distribution in the soil profile, which differs significantly from the quantitative or qualitative distribution of humus in the soil horizons. In general, under the forest vegetation, the content of humus increases, as well as the structure of the soil improves, the permeability and porosity of the upper layer of soil increases. In the course of the literary analysis it became clear that the older the tree plantations, the greater the thickness of the humus horizon below them. In the monitoring sites under the Tilia cordata, there is a tendency to increase the content of humus, hygroscopic moisture, absorption capacity and granulometric composition, indicating improvement of soil conditions. Plantation of Acer platanoides leads to a decrease in the content of total humus in a 0-30-centimeter layer of soil, but with depth this index is gradually increasing. Under the Quercus robus plantations in the surface layer of soil, scientists observed a decrease in humus content, and in the middle layers of soil, on the contrary, an increase in this indicator. With a depth observed leaching of humus. The indicator of humus under Quercus robus is characterized by a significantly higher level of humus, than in black soil. So, the results are typical for humus in zonal chornozems. The data of some authors show that it is in natural forests that the best conditions for the humus accumulation in black soils are formed in comparison with the soils of artificial forests and soils under zonal vegetation (motley grass, Bromus spp., Stipa spp.). Under forest vegetation, leafy deposits form a litter. The Robinia pseudoacacia litter results in improved physical and chemical properties of soils, increases the content of organic matter, exchangeable potassium, absorption capacity, increases aggregate stability and moisture content, decreases $\mathrm{pH}$ and density. Scientific literature notes that the creation of Robinia plantations in soils that have previously lost its forest cover provides an increase in the content and storage of soil organic carbon compared to the Caragana korshinskii plantations. According to our literature data, the most rational measure to increase the soil fertility is the creation of an effective system of protective forest plantations, which are characterized by a favorable integrated influence on the steppe soils.

Keywords: organic matter; organic carbon; forest vegetation

\section{Вплив деревної рослинності на вміст гумусу в чорноземних грунтах}

\author{
А. О. Гуслистий
}

Дніпровський національний університет імені Олеся Гончара, Дніпро, Україна

Проаналізовано літературні джерела стосовно впливу деревної рослинності на вміст гумусу в чорноземних грунтах. У результаті аналізу літературних даних нами виявлено, що деревна рослинність збільшує вміст органічної речовини та 
позитивно впливає на чорноземи. Під кожною деревною породою відбувається характерний і своєрідний для неї розподіл гумусу в грунтовому профілі, який істотно відрізняється від кількісного або якісного розподілу гумусу в грунтових горизонтах. В цілому під лісовою рослинністю збільшується вміст гумусу, а також покращується структурність грунту, збільшується величина водопроникності та пористості верхнього шару грунту. У ході літературного аналізу з'ясовано, що чим старші деревні насадження, тим більша потужність гумусового горизонту під ними. На моніторингових ділянках під насадженнями липи дрібнолистої (Tilia cordata) спостерігається тенденція до збільшення вмісту гумусу, гігроскопічної вологи, ємності поглинання та гранулометричного складу, що свідчить про поліпшення грунтових умов. Насадження клену гостролистого (Acer platanoides) призводять до зменшення вмісту загального гумусу в 0-30-сантиметровому шарі грунту, але 3 глибиною цей показник поступово збільшується. Дані деяких авторів показують, що саме у природних лісах формуються найкращі умови для гумусонакопичення у чорноземних грунтах порівняно із грунтами штучних лісів та грунтами під зональною різнотравно-кострицево-ковиловою рослинністю. Згідно з проаналізованими нами літературними даними, найбільш раціональним заходом підвищення родючості грунтів є створення ефективної системи захисних лісових насаджень, які характеризуються сприятливим комплексним впливом на степові грунти.

Ключові слова: органічна речовина; органічний вуглець; лісова рослинність

\section{Вступ}

Грунти в усьому світі $є$ просторово неоднорідними середовищами, які містять приблизно $2,3 \cdot 10^{9}$ т вуглецю в різних формах (Stockmann et al., 2013). Таким чином, вони $\epsilon$ найважливішим у світі наземним вуглецевим депо, в якому міститься більше вуглецю, ніж зберігається у фітомасі та атмосфері (Scharlemann et al., 2014). У той же час грунти $є$ центральним ресурсом для виробництва продуктів харчування швидко зростаючого населення світу (McBratney et al., 2014).

У XXI столітті зміни природного середовища, клімату, дефіцит енергії та продовольства, деградація грунтів та зниження стійкості екосистем виносяться на передній план як глобальні проблеми. Разом з цим існує серйозна проблема, пов'язана 3 дегуміфікацією грунтів як орних земель, так i лісових масивів, що зумовлено перш за все вирубкою лісів та погіршенням стану навколишнього середовища, а також вітровою ерозією (Lal, 2004; Allen et al., 2009), якій систематично піддається понад 6 млн га території України (Gorban, 2009). Вирубка лісу зменшує кількісні та погіршує якісні показники органічної речовини у грунті (Achat et al., 2015; Nambiar and Harwood, 2014; Mathers et al., 2003).

Метою нашої роботи є аналіз літературних джерел, які стосуються досліджень особливостей впливу деревної рослинності на вміст гумусу в чорноземах степової зони.

Органічна речовина як невід'ємна частина трунту. Говорячи про грунтові органічні речовини, I. В. Тюрін (Tyurin, 1937) підкреслював, що «вся эта система динамична по своей природе и в ней непрерывно происходят изменения, причем масштаб этих изменений, очевидно, находится в обратном соотношении с величиной общего запаса гумуса в почве».

I. I. Назаренко та ін. (Nazarenko et al., 2004) відмічають, що органічна речовина є невід'ємною складовою частиною будь-якого грунту, тобто сукупністю живої біомаси й органічних решток рослин, тварин, мікроорганізмів, продуктів їх метаболізму і специфічних новоутворених темнозабарвлених гумусових речовин, що рівномірно пронизують грунтовий профіль. Складний комплекс органічних сполук грунту зумовлений різним складом органічних решток, що надходять у грунт, неоднаковою спрямованістю мікробіологічного процесу, різноманітними гідротермічними умовами тощо. У складі органічної речовини грунту знаходяться всі хімічні компоненти рослин, бактеріальної та грибної плазми, а також продуктів їх подальшої взаємодії й трансформації. Це тисячі сполук, середній час існування яких у грунті може варіювати від доби до тисяч років (Nazarenko et al., 2004).

Органічна речовина бере участь в утворенні грунтових агрегатів і підвищує їх стійкість до порушення (Semenov \& Kogut, 2015; Degtyarjov, 2011). Зниження вмісту органічної речовини в орному шарі грунтів порівняно 3 гумусовими горизонтами цілинних грунтів призводить до погіршення його структурного стану: збільшення глибистості, зменшення вмісту агрегатів, зниження водопроникності та пористості агрегатів (Kuznetsova, 1994; Degtyarjov et al., 2017).

Рослинні та кореневі залишки, залишки мікроорганізмів та продукти їх трансформації сприяють утворенню органічної речовини у грунтах (KoheelKnabner, 2002; Rasse et al., 2005). Рослинні залишки виступають засобом формування грунтових агрегатів $\mathrm{i}$ поліпшення структури, фактором регулювання рухливості елементів мінерального живлення, поживним i енергетичним субстратом для мікроорганізмів, продуцентом низькомолекулярних розчинних органічних сполук, що мають принципове значення в метаболізмі грунту. Під рослинними залишками в сучасній світовій літературі розуміють, як правило, всю побічну продукцію культур, що надходить або закладається в грунт. Таке розуміння виправдано, враховуючи вимогу обов'язкового повернення в грунт рослинної біомаси, яка не використовується в господарських цілях. В цьому випадку вирішальними факторами стають розміри побічної продукції i ступінь ऑii використання на господарські потреби (Semenov \& Kogut, 2015).

Датський лісничий Р. Е. Мюллер (Müller, 1887) був одним із перших, хто відзначав відмінності в накопиченні гумусу під різною лісовою рослинністю. Пізніше інтерес до впливу видів дерев на грунти був зосереджений на параметрах родючості грунту, на педологічному впливі різних видів дерев та можливих екологічних проблемах, що виникають (Zinke, 1962; Binkley, 1995; Binkley \& Giardina, 1998). Для цілеспрямованого використання деревних порід необхідно визначити, які процеси контролюють відмінності запасів та дослідити форми i стабільність вуглецю у грунті.

Джонсон Д. В. (Johnson, 1992) у своєму літературному огляді ефекту управління лісовим господарством щодо зберігання грунтової органічної речовини дійшов висновку, що вплив деревних порід на грунтовий органічний вуглець часто був значним, але суперечливим.

Під лісовою рослинністю рослинний опад утворює підстилку, участь коренів у гумусоутворенні незначна. По профілю вміст кореневих решток із глибиною зменшується. Ці залишки нерідко використовуються грунтовою фауною та мікроорганізмами, внаслідок чого відбувається трансформація органічної речовини у вторинні форми (Nazarenko et al., 2004).

Вилив деревної рослинності на вміст гумусу. Бінклі та Джардіна (Binkley \& Giardina, 1998) також зазначили, що вплив видів на запаси грунтової органічної речовини відсутні в експериментальних дослідах на одному і тому ж місці. Вони синтезували глобальні різниці між різними деревами лісових масивів і встановили, що в звичайних садових ділянках частота мас зазвичай відрізнялася на $20 \%$, але різниця часто була більшою. 3 моменту публікації цих двох оглядів було опубліковано ряд експериментальних досліджень щодо видів дерев та грунтової органічної речовини, але вони теж не є повними. 
Д. Ф. Соколов (Sokolov, 1962) установив залежність процесів накопичення гумусу як від видового складу деревно-чагарникової рослинності, так і від умов розкладання та мінералізації рослинних залишків.

П. Г. Адерихін, О. Л. Бельгард, С. В. Зонн, І. А. Крупеніков, А. П. Травлєєв (Aderykhin et al., 1983) відзначають, що лісова рослинність впливає на чорноземні грунти та збільшує вміст органічної речовини.

I. T. Степанець (Stepanets, 1963) відзначає, що 10-річне зростання березових та в'язових насаджень сприяє змінам деяких фізико-хімічних та біологічних властивостей деяких типів грунтів. Під лісовою рослинністю покращується структурність грунту, збільшується вміст гумусу та величина водопроникності, а також пористість верхнього шару грунту.

Значну роботу 3 дослідження впливу лісових насаджень на грунтотвірний процес та родючість степових грунтів виконав П. Є. Соловйов (Solovyov, 1967). Учений наводить дані, що в звичайних чорноземах під лісовими насадженнями значно покращились хімічні властивості. Чим старші деревні насадження, тим більшою стала потужність гумусового горизонту.

Морфологічне дослідження грунтотворних процесів під лісовими насадженнями Криворіжжя (Україна), виконане Є. Д. Ющуком (Yuschuk, 2009), виявило фактичні позитивні зміни чорноземів під лісовими насадженнями.

Моніторинг грунтів ботанічного саду Харківського державного університету виконувався Н. М. Цвєтковою та I. I. Сараненко (Tsvetkova \& Saranenko, 2018). Згідно 3 даними вчених у період 2014-2018 рр. під насадженнями липи дрібнолистої (Tilia cordata Mill, 1768) спостерігалося збільшення вмісту гумусу, гігроскопічної вологи та ємності поглинання на дослідних ділянках. Також спостерігається зміна гранулометричного складу з легкого суглинка на важкий, що свідчить про покращення природних властивостей грунту.

В. М. Савосько та А. А. Бахметова (Savosko \& Bahmetova, 2011) при дослідженні гумусу в грунтах Довгинцівсього дендропарку (м. Кривий Ріг, Україна) виявили, що основні запаси гумусу знаходяться у метровому шарі грунтів під деревними насадженнями. У поверхневому шарі грунту вчені спостерігали зменшення вмісту гумусу, а в середніх шарах грунту, навпаки, збільшення цього показника (під насадженнями Betula pendula Roth та Quercus robur L.). 3 глибиною спостерігали вилуговування гумусу під насадженнями Quercus robur L. та Pinus sylvestris L.. Такі результати є типовими для вмісту гумусу в зональних чорноземах.

При дослідженні умісту загального гумусу в чорноземах типових Роганського стаціонару В. В. Дегтярьов (Degtyarjov, 2011) зазначає, що особливий вплив на процеси гумусонакопичення здійснюе деревна рослинність. Чорноземи типові під дубом черешчатим (Quercus robur L.) характеризуються значно вищим умістом загального гумусу порівняно 3 орними чорноземами. Порівняно 3 чорноземом перелогу, грунт під лісосмугою містить менше гумусу лише в поверхневому шарі. 3 глибиною чорнозем лісосмуги стає більш гумусованим, ніж чорнозем перелогу. Автор поясняє це тим, що нижні шари грунту лісосмуги отримують більше рослинних решток.

Як свідчать результати досліджень Н. П. Тупіки (Tupika, 1985), чорноземи звичайні, що формуються під зональною різнотравно-кострицево-ковиловою рослинністю, у верхньому горизонті містять 5,14 \% загального гумусу. Із глибиною спостерігається поступове зменшення його вмісту. Середнє значення вмісту гумусу у цих грунтах складає $3,25 \%$. Верхній горизонт чорноземів лісопокращених, які утворюються під штучною лісовою рослинністю, характеризується збільшеними значеннями концентрації гумусу $(6,0 \%)$ порівняно 3 чорноземами звичайними. Середне значення вмісту гумусу становить $3,53 \%$.
Чорноземи лісові, сформовані у природних байрачних лісах степової зони, відрізняються максимальним вмістом гумусу у верхньому горизонті $(8,81 \%)$. Середне значення вмісту гумусу в чорноземах лісових дорівнює $3,63 \%$. Виходячи 3 наведених даних можна стверджувати, що саме у природних лісах формуються найкращі умови для гумусонакопичення у чорноземних грунтах.

Результати досліджень К. Маррукі (Marruki, 1993), К. Б. Новосада (Novosad, 2004), В. В. Дегтярьова (Degtyarjov, 2005) показали, що деревна рослинність здійснює особливий вплив на гумусовий стан чорнозему типового. Авторами установлено, що сорокадворічні насадження клену гостролистого (Acer platanoides L.) призводять до зменшення вмісту загального гумусу в 0-30-сантиметровому шарі грунту і до деякого зростання його кількості у більш глибоких шарах чорнозему. Так, у верхній частині гумусово-акумулятивного горизонту чорнозему під лісосмугою вміст загального гумусу становить в середньому 8,54 \%, що всього на 6,7 \% нижче відносно грунту абсолютної цілини. У нижніх досліджуваних шарах (30-50 см) уміст загального гумусу зростає порівняно з абсолютно цілинним грунтом на $0,22-$ $0,54 \%$. Автори вважають, що це пов'язано 3 особливостями морфології деревної рослинності, яка зосереджує основну масу коренів у нижніх шарах грунту.

Додавання листків робінії до грунтів зумовлює покращення фізичних та хімічних властивостей грунтів, зокрема збільшується вміст органічних речовин, обмінного калію, ємності поглинання, підвищується стійкість агрегатів та здатність утримувати вологу, зменшується значення рН та щільності (Khan et al., 2010). Зростання $R$. pseodoacacia призводить до збільшення вмісту органічних речовин та азоту, що, у свою чергу, відображається на стані асиміляційного апарату самого насадження, зокрема на питомій поверхні та площі листка, вмісті води в листках, загальному вмісті азоту та органічних речовин у листках (Duan et al., 2017). Li et al. (2017) відзначають, що створення робінієвих насаджень на грунтах, які до цього втратили лісовий покрив, забезпечує краще збільшення вмісту та зберігання грунтового органічного вуглецю порівняно 3 насадженнями Caragana korshinskii, а також угрупованнями Stipa bungeana + Artemisia gmelinii. При цьому автори зазначають, що робінія краще забезпечує збільшення органічної речовини в лісових грунтах порівняно 3 піщаними грунтами (Gorban \& Huslystyi, 2018).

М. В. Ключников та ін. (Klyuchnikov et al., 2011) дослідили вміст гумусу в орному шарі чорнозему південного під деревними породами. Під березою в гумусовому горизонті його міститься більше, ніж під сосною і тополею. Найбільш сильний вплив робить на накопичення гумусу у верхньому горизонті модринове насадження (Larix Miller 1754). Тут його більше на $15 \%$ в порівнянні 3 перелогом і на 4,45 \% більше, ніж під березою. Причому і його розподіл за профілем виявляється більш істотним. Так, на глибині 80 см питома вага гумусу становить під модриною 3,0 \%, що значно вище його вмісту під пологом інших деревних порід.

Згідно $з$ даними Е. Б. Смирнової та ін. (Smyrnova et al., 2012) закономірності зміни гумусового стану пов'язані, перш за все 3 типом землекористування. Саме характер використання міських грунтів багато в чому пояснює розподіл гумусу за їхнім профілем. За даними ФГБУ Станція агрохімічної служби «Балашовська», в 80-90-х роках минулого сторіччя вміст гумусу в шарі 0-10 см в чорноземах звичайних становив у середньому по 20 реперних ділянках $6,2 \%$. Коливання по окремих розрізах були дуже значні - від 5,7 до 7,4 \%. Порівняно поступово зменшувався вміст гумусу вниз по профілю: від 5,9\% до 2,0 \% на глибині 10 см (Zanina et al., 2009). Однак під час дослідження авторами вміст гумусу в орному шарі чорнозему звичайного в результаті дегуміфікації становив 
5,2 \%. У грунтах лісопарків спостерігається збільшення гумусованості поверхневого шару. За 50 років вміст гумусу на рівні 6,2 \% є середньостатистичною величиною. Більш того, на ділянках, де під деревами відзначені густий підлісок і хороший травостій, вміст гумусу досягає від 6,2 до $7,9 \%$. Це є наслідком розвитку дернового процесу, оскільки в містах лісостепової та степової зон не прийнято внесення органічних добрив в грунти парків, а тим більше лісопарків. Досить високий рівень природної родючості грунтів робить цей прийом необов'язковим. Таким чином, лісова рослинність покращує фізико-хімічні властивості чорноземів звичайних і сприяє підвищенню їх родючості, що пов'язано 3 інтенсифікацією процесу накопичення гумусу i, як наслідок, з різким збільшенням вмісту гумусу у верхніх горизонтах (Smyrnova et al., 2012).

Дослідження А. Г. Болотова та ін. (Bolotov et al., 2014) 3 вивчення впливу полезахисних лісосмуг, що складаються 3 листяних порід (берези повислої, тополі бальзамічної, дуба черешчатого), на властивості чорноземів вилуженого і південного Приобського плато показали, що найбільший вміст гумусу відзначається у верхніх грунтових горизонтах під березою (4-5\%). Особливо це помітно в чорноземі вилуженому дослідної ділянки (5\%). Показники вмісту гумусу тут майже на $30 \%$ вищі, ніж у верхніх горизонтах контрольної ділянки на перелозі $(3,4 \%)$. Очевидним $є$ наочний прояв однієї зі сторін грунтопокращуючої дії деревної породи на грунт. У чорноземі південному під березою і на перелозі вміст гумусу у верхніх грунтових горизонтах практично однаковий. Під дубом процентний вміст гумусу у верхніх грунтових горизонтах також близький до перелогу, а під тополею спостерігаються нижчі показники, ніж на перелозі. Автори вважають, що це пов'язано 3 особливостями надходження і розкладання органічної речовини опаду від даних порід і розкладання відмерлих коренів деревних і трав'янистих рослин. Під усіма деревними породами на обох чорноземах було виявлено більш високий вміст гумусу в перехідному горизонті порівняно з перелогом, що також свідчить про вплив деревних порід на грунтоутворювальний процес.

Ю. В. Бехових (Bekhovyh, 2017) також проводив дослідження чорнозему вилуженого під деревними насадженнями Приобського плато. Дослідження автора показали, що найбільший вміст гумусу в дерновому горизонті відзначається під модриною. Це, очевидно, пов'язано 3 особливостями надходження органічної речовини опаду під даною деревною породою. Найменший вміст гумусу в дерновому горизонті було виявлено під дубом. Найвищий вміст гумусу в гумусовому горизонті $\mathrm{i}$ перехідному горизонті було виявлено під березою i модриною. Найнижчий вміст гумусу в цих горизонтах було виявлено під ялиною, оскільки їі рослинні залишки грубіші і їх накопичення переважає над розкладанням. В цілому грунтовий профіль під ялиною виділяється більш низьким процентним вмістом гумусу серед всіх розглянутих деревних порід. Грунтовий профіль під дубом виділяється практично рівномірним вмістом гумусу включно до перехідного горизонту 3 грунтоутворюючою породою. Таким чином, під кожною деревною породою відбувається характерний і своєрідний для неї розподіл гумусу в грунтовому профілі, який істотно відрізняється від кількісного або якісного розподілу гумусу в грунтових горизонтах перелогової ділянки. Так, під модриною i ялиною відбувається поступове зменшення вмісту гумусу при переході від одного горизонту до іншого, так само і на перелозі, однак помітна відмінність у процентному вмісті. Під березою в перехідному горизонті відбувається накопичення гумусу, і тут його вміст навіть вищий, ніж у дерновому горизонті і гумусовому горизонті. Під дубом, як уже було відзначено вище, вміст гумусу в грунтових горизонтах практично однаковий. Перехідний горизонт під цією деревною породою виділяється серед інших порід тим, що в ньому вміст гумусу вдвічі вищий, ніж під модриною і березою, і в 14 разів вищий у порівнянні 3 ялиною. Це $\epsilon$ очевидним свідченням впливу деревних порід на грунтоутворюючий процес та формування своєрідних і характерних грунтових профілів під ними.

А. К. Поляков та О. Н. Торохова (Polyakov \& Torohova, 2006) під час дослідження динаміки агрохімічних властивостей грунтів під деревними насадженнями Донецького ботанічного саду виявили, що різні деревні породи по-різному впливають на родючість грунтів. Автори дослідили, що вміст гумусу у грунті закономірно зменшується від поверхневих горизонтів до нижчих. Якщо у верхньому горизонті (0-10 см) відзначено 5,0-7,6 \% гумусу, то на глибині 40-60 см цей показник становить $2,6-4,7 \%$. Найбільший вміст гумусу зафіксовано в грунтах на ділянках степу, в насадженнях ліщини деревовидної i клена гостролистого - 7,0-7,6 \%. У насадженнях Tilia cordata Mill, Betula pendula Roth, Carpinus betulus L., Fraxinus excelsior L., Sorbus intermedia (Ehrh.) Pers., Larix sibirica Ledeb., а також представників сімейств бобових i цезальпінеєвих (Robinia pseudoacacia L., Gleditsia triacanthos L., Cladrastis lutea (Michx) C.Koch, Sophora japonica L.) вміст гумусу становить 6,0-6,9 \%. Нижчі показники (5,2-5,8 \%) відмічені в насадженнях дуба черешчатого і дуба червоного, сосни звичайної та сосни кримської, ялини звичайної та ялівця віргінського. Автори зазначають, що родючість грунтів у насадженнях різних деревних порід визначається неоднаковою швидкістю мінералізації опаду, перетворення його в гумус i накопичення гумусу в діяльному шарі грунту. Це обумовлює поступове підвищення вмісту гумусу в межах $0,1-0,3 \%$ за 10-річний період.

У світовій літературі існує багато праць різних вчених 3 різних країн світу щодо питань вивчення вмісту органічної речовини в грунті під різними типами насаджень. Виходячи 3 цього, виникає нагальна необхідність проведення комплексних досліджень гумусу еталонних чорноземів звичайних. Окремо стоїть питання впливу штучних лісових насаджень різного деревного складу та світлової структури на комплексні характеристики висхідних чорноземів звичайних. Важливість виконання зазначених досліджень зумовлена комплексною екологічною роллю, яку відіграє у грунтах гумус. Зокрема, один із важливих показників родючості грунтів - їх поглинальна здатність, яка забезпечується колоїдальною складовою грунту та колоїдним гумусом. Ця форма гумусу виконує роль джерела основних елементів живлення рослин і зумовлює фізичні, фізико-механічні та хімічні показники грунтів, їх мікробіологічну активність (Degtyarjov, 2011).

\section{Висновки}

У наш час спостерігається інтенсивна дегуміфікація степових грунтів, що пов'язано 3 нераціональним використанням грунтового покриву в сільськогосподарському виробництві, а також катастрофічним станом полезахисних лісонасаджень в умовах степової зони. Згідно 3 проаналізованими літературними джерелами найбільш раціональним заходом щодо загального підвищення родючості чорноземів, в тому числі за рахунок збільшення в них вмісту гумусу, $\epsilon$ створення ефективної системи захисних лісових насаджень, які характеризуються сприятливим комплексним впливом на степові грунти.

\section{References}

Achat, D. L., Deleuze, C., Landmann, G., Pousse, N., Ranger, J., Augusto, L. (2015). Quantifying consequences of removing harvesting residues on forest soils and tree growth - A metaanalysis. Forest Ecology and Management, 348, 124-141. DOI: $10.1016 /$ j.foreco.2015.03.042. 
Aderikhin, P. G., Belgard, A. L., Zonn, S. V., Krupenikov, I. A., \& Travelyev, A. P. (1983). Vliyaniye lesnoy rastitel'nosti na chernozemy [Influence of forest vegetation on chernozems]. Russian black earth -100 years after Dokuchaev. Moscow, 117-126 (in Russian).

Allen, M. R., Frame, D. J., Huntingford, C., Jones, C., Lowe, J., Meinshausen M., \& Meinshausen N. (2009). Warming caused by cumulative carbon emissions towards the trillionth tonne. Nature, 458, 1163-1166. DOI: 10.1038/nature08019.

Bekhovykh, Yu. V. (2017). Fiziko-khimicheskiye svoystva chernozema vyshchelochennogo Altayskogo Priob'ya pod razlichnymi drevesnymi porodami polezashchitnykh lesopolos [Physical and chemical properties of leached chernozem of the Altai Priobye under various tree species of forest shelter belts]. Bulletin of the Altai State Agrarian University, 7(153), 68-72 (in Russian).

Binkley, D., \& Giardina, C. (1998). Why do tree species affect soils? The warp and woof of tree-soil interactions. Biogeochemistry, 42, 89-106. DOI: 10.1007/978-94-0172691-7 5.

Binkley, D., (1995). The influence of tree species on forest soils: processes and patterns. In: Mead, D.J., Cornforth, I.S. (Eds.), Proceeding of the Trees and Soil Workshop, Lincoln University 28 February-2 March (1994). Lincoln University Press, Canterbury, 1-33.

Bolotov, A. G., Bekhovykh, Yu. V., Sizov, E. G., \& Poskotinova, O. N. (2014). Fiziko-khimicheskiye svoystva chernozemov pod listvennymi lesopolosami [Physical and chemical properties of black soils under deciduous forest belts]. Bulletin of the Altai State Agrarian University, 5(115), 56-62 (in Russian).

Degtyarev, V. V. (2005). Mineralna matrytsya yak osnova gruntovoyi matrytsi [Mineral matrix as the basis of a soil matrix]. Bulletin of Kharkiv National Agrarian University, 1, $85-88$

Degtyarev, V. V. (2011). Humus chornozemiv livoberezhnoho Lisostepu i Stepu Ukrayinu [Humus of chernozems Foreststeppe and Steppe of Ukraine]. Kharkiv, Majdan (in Ukrainian).

Degtyarjov, V. V., Yatsuk, I. P., \& Usata, R. Yu. (2017). Influence of different systems fertilizer on the content of actualy humic substances and detritus in the meadow-chernozem soils of the right-bank forest-Steppe of Ukraine. Bulletin of Kharkiv National Agrarian University, 2, 64-77.

Duan, Y.-Y., Song, L.-J., Niu, S.-Q., Huang, T., Yang, G.-H., \& Hao, W.-F. (2017). Variation in leaf functional traits of different-aged Robinia pseudoacacia communities and relationships with soil nutrients. Chinese Journal of Applied Ecology, 28(1), 28-36. DOI: $10.13287 / j .1001-$ 9332.201701.036.

Gorban, V. A., \& Huslystyi, A. O. (2018). Some features of the influence of Robinia pseudoacacia L. on soils in arid conditions. Ecology and Noospherology, 29(1), 47-51 (in Ukrainian). DOI: 10.15421/031808.

Gorban, V. A. (2009). Vplyv eolovo-gruntovykh vidkladiv na komponenty ta strukturni elementy lisovykh kulturbioheotsenoziv stepovoyi zony Ukrayiny [Influence of eolian-soil depths on components and structural elements of forest cultures on biogeocoenoses of the steppe zone of Ukraine]. Gruntoznavstvo, 10(1-2), 90-94 (in Ukrainian).

Johnson, D. W. (1992). Effects of forest management on soil carbon storage. Water Air Soil Pollut. 64, 83-120. DOI: 10.1007/BF00477097.

Khan, B., Ablimit, A., Mahmood, R., \& Qasim, M. (2010). Robinia pseudoacacia leaves improve soil physical and chemical properties. Journal of Arid Land, 2(4), 266-271.

Klyuchnikov, M. V., Paramonov, E. G., \& Trofimov, I. T. (2011). Vliyaniye listvennitsy na svoystva chernozemov yuzhnykh $\mathrm{v}$ zasushlivoy stepi [The influence of larch on the properties of southern chernozems in the arid steppe]. World of Science, Culture, Education, 1 (26), 351-353 (in Russian).
Kogel-Knabner, I. (2002) The macromolecular organic composition of plant and microbial residues as inputs to soil organic matter. Soil Biology and Biochemistry, 34, 139-162. DOI: 10.1016/S0038-0717(01)00158-4.

Kuznetsova, I. V. (1994). Rol organicheskogo veshchestva v obrazovanii vodoprochnoy struktury dernovo-podzolistykh pochv [The role of organic matter in the formation of waterstable structure of sod-podzolic soils]. Eurasian Soil Science, 11, 34 41 (in Russian).

Lal, R. (2004). Soil carbon sequestration impacts on global climate change and food security. Science, 304, 1623-1627. DOI: 10.1126/science.1097396.

Li, Y. J., Hu, S., Jiao, J. Y., \& Wu, D. Y. (2017). Response of soil organic carbon to vegetation rest oration in different erosion environments in the hilly-gullied region of the Loess Plateau. Shengtai Xuebao. Acta Ecologica Sinica, 37(12), 4100-4107. DOI: $10.5846 /$ stxb201606161168.

Marruki, K. (1993). Vliyaniye lesnoy i travyanistoy rastitel'nosti na osnovnyye kharakteristiki chernozema tipichnogo moshchnogo slabosmytogo yugo-vostoka Lesostepi Ukrainy [The influence of forest and grass vegetation on the main characteristics of the chernozem of typical weakly washed out southeast of the Forest-Steppe of Ukraine]. Avtoref. dis. Kharkov (in Russian).

Mathers, N. J., Mendham, D. S., O'Connell, A. M., Grove, T. S., Xu, Z. H., \& Saffigna, P. G., (2003). How does residue management impact soil organic matter composition and quality under Eucalyptus globulus plantations in Southwestern, Australia? Forest Ecology and Management, 179, 253-267. DOI: 10.1016/S0378-1127(02)00527-3.

Müller, P. E. (1887). Studien über die natürlichen Humusformen und deren Einwirkungen auf Vegetation und Boden. Julius Springer, Berlin, 324. DOI: 10.5962/bhl.title.20253

Nambiar, E. K. S., \& Harwood, C. E. (2014). Productivity of acacia and eucalypt plantations in Southeast Asia. International Forestry Review, 16, 225-248. DOI: 10.1505/146554814811724766.

Nazarenko, I. I., Polchina, S. M., \& Nikorich, V. A. (2004). Gruntoznavstvo: Pidruchnyk [Soil Science: Textbook]. Chernivtsi (in Ukrainian).

Novosad, K. B. (2004). Evolyutsiya chornozemiv typovykh hlybokykh pivdenno-skhidnoho Lisostepu Ukrayiny pid riznymy fitotsenozamy [Evolution of chernozem typical of deep southeastern forest-steppe of Ukraine under various phytocoenoses]. Avtoref. dis. Kharkov (in Ukrainian).

Polyakov, A. K, \& Torokhov, O. N. (2006). Dinamika pochvennogo plodorodiya $\mathrm{v}$ kollektsionnykh nasazhdeniyakh Donetskogo botanicheskogo sada NAN Ukrainy [Dynamics of soil fertility in collecting plantings of the Donetsk botanical garden of the National Academy of Sciences of Ukraine]. Industrial Botany, 6, 199-203 (in Russian).

Rasse, D. P., Rumpel, C., \& Dignac, M-F. (2005) Is soil carbon mostly root carbon? Mechanisms for a specific stabilisation. Plant and Soil, 269, 341-356. DOI: https://doi.org/10.1007/s11104-004-0907-y.

Savosko, V. M. \& Bahmetova, A. A. (2011). Vmist humusu v gruntakh pid providnymy nasadzhennyamy Dovhyntsivskoho dendroparku (m. Kryvyy Rih) [The content of humus in soils under the dominant plantations of the Dovgintsy Dendroparks (Kryvyi Rih)]. Issues of steppe forestry and forest eclamation of soils, 40, 81-88 (in Ukrainian)

Scharlemann, J. P. W., Tanner, E. V. J., Hiederer, R., \& Kapos, V. (2014). Global soil carbon: understanding and managing the largest terrestrial carbon pool. Carbon Manag. 5, 81-91. DOI: 10.4155/cmt.13.77.

Semenov, V. M., \& Kogut, B. M. (2015). Pochvennoye organicheskoye veshchestvo [Soil Organic Substance]. Moscow (in Russian).

Smirnova, E. B., Reshetnikova, V. N., Stepanov, M. A., \& Makarova T. Yu. (2012). Soderzhaniye gumusa i yego kompleksov s metallami $\mathrm{v}$ chernozome obyknovennom rekreatsionnykh territoriy. [The content of humus and its 
complexes with metals in ordinary chernozem recreational areas]. Proceedings of the Samara Scientific Center of the Russian Academy of Sciences, 1 (8), 2068-2071 (in Russian).

Sokolov, D. F. (1962). Vliyaniye lesnoy rastitel'nosti na sostav gumusa pochv razlichnykh prirodnykh zon [The influence of forest vegetation on the composition of soil humus of various natural zones]. Moscow (in Ukrainian).

Solovyov, P. Ye. (1967). Vliyaniye lesnykh nasazhdeniy na pochvoobrazovatel'nyy protsess i plodorodiye stepnikh pochv [The influence of forest plantations on the soil-forming process and the fertility of steppe soils]. Moscow (in Russian).

Stepanets, I. T. (1963). Vliyaniye lesnykh nasazhdeniy na izmeneniye fizicheskikh i khimicheskikh svoystv temnokashtanovykh pochv Zapadnogo Kazakhstana [The impact of forest plantations on changes in the physical and chemical properties of dark chestnut soils in Western Kazakhstan]. Eurasian Soil science, 9, 75-84 (in Russian).

Stockmann, U., Adams, M. A., Crawford, J. W., Field, D. J., Henakaarchchi, N., Jenkins, M., Minasny, B., McBratney, A. B., de Remy de Courcelles, V., Singh, K., Wheeler, I., Abbott, L., Angers, D. A., Baldock, J., Bird, M., Brookes, P. C., Chenu, C., Jastrow, J. D., Lal, R., Lehmann, J., O'Donnell, A. G., Parton, W. J., Whitehead, D., \& Zimmermann, M. (2013). The knowns, known unknowns and unknowns of sequestration of soil organic carbon. Agriculture, Ecosystems \& Environment, 164, 80-99. DOI: 10.1016/j.agee.2012.10.001.

Tsvetkova, N. M. \& Saranenko, I. I. (2018). Influence of forest plantations of fine-leaved linden on main properties of dark- chestnut soil of agrobiostation - Botanical garden of KSU. ScienceRise: Biological Science, 4(13), 31-35. DOI: 10.15587/2519-8025.2018.141295.

Tupika, N. P. (1985). Kharakteristika gumusnogo sostoyaniya pochv lesnykh biogeotsenozov Prisamar'ya [Characteristics of the humus state of the soils of the Samaria forest biogeocenoses]. Issues of steppe forestry and forest eclamation of soils, 44-48 (in Russian).

Tyurin, I. V. (1937). Organicheskoye veshchestvo pochv i yego rol $\mathrm{v}$ pochvoobrazovanii i plodorodii. Ucheniye o pochvennom gumuse [Soil organic matter and its role in soil formation and fertility. The doctrine of soil humus]. Moscow (in Russian).

Yuschuk, E. D. (2009). Morfolohichne vyvchennya gruntoutvoryuvalnykh protsesiv pid lisovymy nasadzhennyamy Kryvorizhzhya [Morphological study of soil formation processes under forest plantations of Kryvorizhya]. Gruntoznavstvo, 10(3-4), 37-41 (in Ukrainian).

Zanina, M. A., Kurbatov, A. S., \& Grinberg S. Yu. (2009). Dinamika pochvennogo plodorodiya zapadnoy chasti Pravoberezh'ya Saratovskoy oblasti po rezul'tatam agrokhimicheskogo monitoringa [The dynamics of soil fertility of the western part of the Right Bank of the Saratov region according to the results of agrochemical monitoring]. Bulletin of the Saratov State Agrarian University, 8, 22-26 (in Russian).

Zinke, P. J. (1962). The pattern of influence of individual forest trees on soil properties. Ecology, 43, 130-133. DOI: 10.2307/1932049. 